39 Johnson PC, Doll SC, Cromey DW: Pathogenesis of diabetic neuropathy. Ann Neurol 1986;19:450-7.

40 Davis PH, Dambrosia JM, Schoenberg BS, et al.: Risk factors for ischemic stroke: a prospective study in Rochester, Minnesota. Ann Neurol 1987;22:319-27.

41 Rogers RL, Meyer JS, Shaw TG, et al.: Cigarette smoking decreases cerebral blood flow suggesting increased risk from stroke. JAMA 1983;250:2796-800.

42 Rogers RL, Meyer JS, Shaw TG, et al:: Reductions in regional cerebral blood flow associated with chronic consumption of alcohol. J Am Geriatr Soc 1983;31:540-3.

43 Obrist WD, Thompson HK, Wang HS, et al. Regional cerebral blood flow estimated by 133 Xenon inhalation. Stroke 1975;6: 245-56.

44 Meyer JS, Ishikawa N, Deshmukh VD, et al. Improved method for noninvasive measurement of regional cerebral blood flow by 133 Xenon inhalation. Stroke 1978;9:195-205.

45 Kitagawa Y, Meyer JS, Tachibana H. et al. CT-CBF correlates of cognitive deficits in multi-infarct dementia. Stroke 1984;15:1000-8.

46 O'Brien MD, Mallett BL. Cerebral perfusion rates in dementia.
J Neurol Neurosurg Psychiatry 1970;33:497-500.

47 O'Brien MD. Vascular disease and dementia in the elderly. In: Lynn-Smith W, Kinsborne M. (eds.) Aging and Dementia. New York: Spectrum 1977:77-90.

48 Meyer JS, Rogers RL, Judd BW, et al. Cognition and cerebral blood flow fluctuate together in multi-infarct dementia. Stroke, 1988, 163-9.

49 Roth M. Epidemiological studies. In: Alzheimer's Disease: Senile Dementia and Related Disorders (Aging, vol. 7) Katzman R, Terry RD, Bick AKL eds: New York, Raven Press 1978:337-9.

50 Schoenberg BS, Epidemiology of dementia due to cerebrovascular disease. In: Vascular or Multi-infarct Dementia. Meyer JS, Lechner H, Marshall J, Toole J (eds,): Mount Kisco, N.Y., Futura Publishing Co. 1988, 45-59.

51 Ueshima H, Takako O, Asakura S. Regional differences in stroke mortality and alcohol consumption in Japan. Stroke 1986; 7:19-24.

52 Wolf P, Kannel W. Controllable risk factors for stroke: preventive implications of trends in stroke mortality. In: Meyer JS, Shaw T, (eds.): Diagnosis and Management of Stroke and TIAs. London. Addison-Wesley Publishing Co.: 1982, 25-57.

\title{
Moritz Heinrich Romberg and Ekbom's syndrome
}

As a result of four papers, ${ }^{12}$ the well known syndrome of restless legs is justly credited to KA Ekbom Sr. His seminal paper ${ }^{1}$ referred to "asthenia crurum paraesthetica (Irritable Legs)". His second distinguished two forms: (1) "asthenia crurum paraesthetica" and (2) "asthenia crurum dolorosa"; he later ${ }^{2}$ settled for plain "restless legs syndrome". Others have referred to fidgety feet, and dyslysis. Spillane and colleagues described a similar condition of "painful legs and moving toes" relieved by sympathetic block with local anaesthetic.

Of historical interest is a passage in the English translation of the 2nd edition of Romberg's celebrated $A$ Manual of the Nervous Diseases of Man (1853). ${ }^{3}$ Romberg was a great nosologist, a devotee and translator of the works of Sir Charles Bell and Marshall Hall. He provided good descriptions of, inter alia: progressive muscular atrophy, carpal tunnel syndrome, neuralgic amyotrophy and in 1846 the Parry-Romberg syndrome of progressive hemifacial atrophy. Chapter 9 includes: "Anxietas tibiarum", a sense of painful restlessness in the lower extremities, especially in the legs and feet. The patient "did not know what to do with them. . though there was relief by change of position".

Though modern, symptomatic, empirical treatment is valuable, the aetiology remains an enigma.

\section{References}

1 Ekbom KA. Asthenia crurum paraesthetica ("Irritable Legs"). A new syndrome consisting of weakness, sensation of cold and nocturnal paraesthesia in the legs, responding to a certain extent to treatment in general. Acta Med Scand 1944;118:197-209.

2 Ekbom KA. Restless legs syndrome. Neurology 1960;10:868-73.

3 Romberg MH. A Manual of the Nervous Diseases of Man. 2 vols. Chapter 9: Hyperaesthesia of the Nerves of Muscular Sense. (Trans and ed Sieveking EH, London, The New Sydenham society, 1853. 